\title{
E-procurement adoption in the agro-based sector: a Malaysian perspective
}

\begin{abstract}
User acceptance of technology has been an important field of study for over 2 decades. Numerous models have been proposed to explain and predict the user acceptance of technology. The technology acceptance model (TAM) is one of the most admired models capturing the important aspects of users' intention to adopt technology. Thus, it is essential for anyone willing to study user acceptance of technology to understand TAM. This article analyzes the adoption and utilization of e-procurement in the agro-based sector. The article provides empirical evidence on the attitude and its behavioral intention of using eprocurement in agro-based companies in Malaysia.
\end{abstract}

Keyword: E-procurement; Technology acceptance model; Agro-based sector; Malaysia 